\title{
Unbreakable bonds? The challenge of the motif of adoption to the African neo-Pentecostal belief in generational curses
}

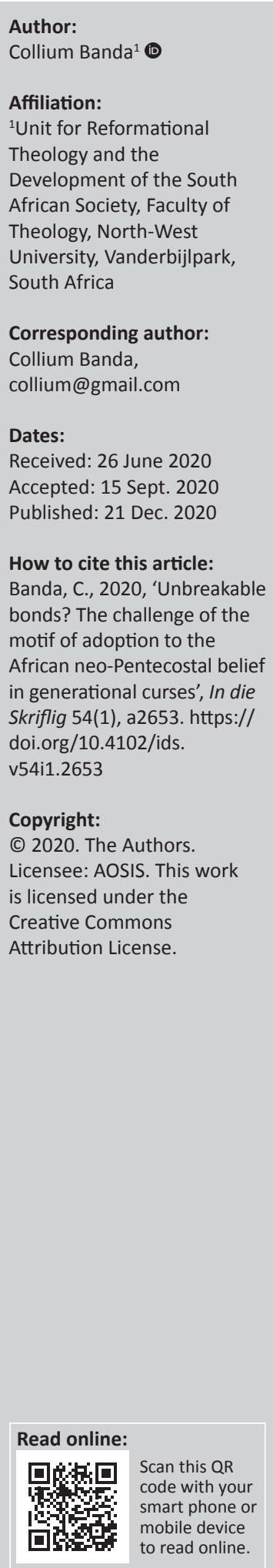

The article uses the motif of salvation as adoption as God's children to critique the African neo-Pentecostal (ANP) belief that generational curses remain on Christians after conversion. A prominent mark that distinguishes ANP churches from classical Pentecostal churches is the prophet-pastors and prophet-apostles whose prophetic stature is foundational to the existence of these churches. The main question answered in the article is: in the light of biblical description of Christians as adopted children of God how should we soteriologically evaluate the ANP claim that born-again Christians remain under curses inherited from their ancestors? Therefore, the ANP view of generational curses is explained, and soteriological adoption is described in relation to the believers' spiritual liberation and security. A proposal is made of how adoption should liberate ANP Christians from the fear of generational curses. The article challenges ANP prophets to critique their teaching on generational curses on Christians by using biblical images of salvation.

Keywords: generational curses; adoption; redemption; African neo-Pentecostalism; sonship; salvation; spiritual security.

\section{Introduction}

The belief in generational curses is prominent in many African neo-Pentecostal (ANP) churches (Biri 2012:3-4, 2018:83-85; Chitando \& Biri 2016:76; Maxwell 1998:361). Other terms for generational curses include ancestral curses and bloodline curses. Although the ANP movement is distinct from classical Pentecostalism, the two movements share the common roots of the Azusa Street Revival, and also share some main characteristics like speaking in tongues. However, the ANP movement mainly distinguishes itself by the emphasis on health and wealth as a sign of God's favour on the Christian and the prominence enjoyed by the selfappointed prophet-pastor or prophet-apostle figures. Because the ANP movement is entirely reliant on the prophetic figures, Kgatle (2017:2) describes it as a movement that 'revolves around personalities'. Although some of the prophetic figures use the title 'pastor' or 'apostle', in this article they are referred to as prophets because the prophetic element is a dominating factor among the ANP leaders.

A major teaching of the ANP prophets is that, in addition to salvation, Christians must undergo special spiritual deliverance rituals, often under a spiritually powerful 'man of God', to be liberated from generational curses (Degbe 2014:256; Makandiwa 2018f). Delivering people from generational curses is a lucrative enterprise among some ANP prophets (Kgatle 2019:2; Mahohoma 2017:4). The ANP prophets believe that born-again Christians remain subject to generational curses until they undergo special deliverance services (Biri 2018:83; Mahohoma 2017:3-4). This teaching raises questions about the power of Christ and his salvation to liberate and protect believers from evil spirits. As a soteriological problem, the fear of generational curses questions the state and extent of the power of salvation on the believer. The consuming fear of generational curses is not limited to ANP Christians. It is one of the fears that drives African Christians from the conservative traditional churches to seek the services of ANP prophets.

A previous article critiqued the ANP teaching of generational curses from the perspective of salvation as being born again (Banda 2020). This article takes the discussion further by dealing with the issue from the view of salvation as adoption as God's children. The main question of this article is: in the light of the biblical description of Christians as adopted children of God, how should we soteriologically evaluate the ANP claim that born-again Christians remain under 
curses inherited from their ancestors? The main aim of this article is to subject the ANP belief in generational curses to the scrutiny of the soteriological metaphor of adoption as God's children. Although the motif of adoption is biblically derived, this article treats the concept from a systematic theological method. Therefore, extensive biblical exegetical technicalities fall outside the main purposes of the article. This article understands the motif of adoption as describing the state of spiritual blessedness that God gives to Christians at conversion. In essence, this article challenges ANP Christians to critically reflect on their fear of generational curses from a biblically informed soteriology. This soteriology must instil confidence in Christians, instead of filling them with fear by magnifying the power of the evil over Christians.

\section{The African neo-Pentecostal belief in generational curses}

There are various strands of the ANP belief in generational curses, just as there are many different prophets who teach the doctrine. At the centre of the doctrine is that ancestors pass to their descendants their unfavourable spiritual conditions such as the guilt of their sins, ill-luck, poverty and undesirable personal characteristics such as shorttemperedness and sinful habits like stealing (Biri 2018:83-84; Meyer 1998:324-327). African neo-Pentecostal prophets teach that Christians remain under generational curses until they undergo special deliverance services under spiritually gifted (anointed) prophets (Degbe 2014:255; Makandiwa 2018b). African neo-Pentecostal prophets derive the basic substance of their teaching about generational curses from biblical texts such as Exodus 20:4-5, Numbers 14:18 and Deuteronomy 5:9 where God promises to punish the children for the sins of their fathers to the third and fourth generations (Degbe 2014:255). Emmanuel Makandiwa (2018c), a Zimbabwean Pentecostal prophet, says a generational curse is 'going through problems because of what your parents $\mathrm{did}^{\prime}{ }^{1}$ Makandiwa (2018b) argues that some of people's present suffering results from the sins committed by their ancestors. Makandiwa says a man from a polygamous father has polygamy in his genes that works against his desire for monogamy (Makandiwa 2018d). Therefore, generational curses are '[negative] events from the past that affect the present in negative ways' (Asamoah-Gyadu 2004:390).

In addition to the guilt of sins, to ANP churches, generational curses include evil spells cast on people to bring negative conditions such as poverty, sickness, failed marriages, inability to find a marriage partner and vagrancy within the family line (Makandiwa 2018b). Ideally, this view of curses epitomises witchcraft. This view of curses ultimately means that they are Satan's evil work against believers. Makandiwa (2018f) further states, 'when the blood [of a person] is cursed, it ceases to operate well', which means that according to generational curses people inherit a damaged operational

1.Prophet Emmanuel Makandiwa leader of the United Family International Ministries, with its with its headquarters in Harare, Zimbabwe, broke away from the Apostolic Faith Mission in Zimbabwe, a conservative classical Pentecostal church. Makandiwa is one of the prominent faces of African neo-Pentecostalism in Southern Africa. system from their ancestry. In essence, situations like intergenerational poverty, operational evil are attributed to evil spiritual conditions inherited from the family ancestry that hinder people from attaining prosperity and good health (Makandiwa 2018a, 2018b, 2018c, 2018f, 2018g). Sometimes generational curses are explained in terms of inheriting demons in the family line, or being possessed by what they call territorial spirits, which are particular evil spirits that are believed to control geographical locations, so that those areas are rife with particular social evils such as murder and sexual immorality (Mahohoma 2017:8-9).

A critical assessment of the ANP belief in generational curses reveals the incorporation of African traditional religious concepts. In African traditional religions (ATR) occurrences in life are often attributed to spiritual causes (Mbiti 1990:1-5). For example, traditional Zimbabwean Ndebele people believe that there are ancestral spirits that cause poverty, amadlozi obuyanga. Traditional Shona people do consult traditional healers to fortify their children against the spirit of vagrancy - urombe. It is common to hear traditional people seeking cleansing of ill-luck (umnyama) that is hindering them from obtaining success. It is also believed people who practise undesirable acts, such as witchcraft, pass these evil traits on to their descendants. Among traditional Zimbabweans, the fear of the consequences of the guilt of the ancestors can be seen in the fear of the avenging spirits, uzimu (in Ndebele) and ngozi (in Shona) (Taringa 2006:199). The belief is that the consequences of the ancestors' actions and their spiritual condition spread to the descendants, hence people live in fear of the consequences of the guilt and condition of their ancestors. Therefore, a problem with the ANP belief in generational curses is that Christians seem to replicate the same worldview of generational curses found in ATR. The point of contention is that ANP Christians use a similar worldview to the one in ATR adherents to interpret their lived experiences and struggles in life.

Furthermore, the ANP prophets' basing of their teaching on generational curses on Old Testament passages like Exodus 20:4-5 and Deuteronomy 5:9 where God promises to punish the children for the sins of their parents to third and fourth generation has several theological problems. Firstly, God's command that children shall not be punished for the sins of their parents because each person must die for his or her own sins (Dt 24:16; 2 Ki 14:6), shows that passages like Exodus 20:4-5 refer to the effects of the sinful pattern of the parents, not that children pay for the sins of their parents. God is just. The verses emphasise that children walk in the ways of their parents resulting in the sins of the parents becoming the sins of the children. Secondly, a fundamental flaw in the ANP prophets' teaching on generational curses lies in the prominence given to the mediatory role of prophets in breaking or reversing the curses that ultimately diminishes the role of repentance in escaping God's wrath. Biblically, the way of escaping God's wrath is repentance, which is the mending of a broken relationship with God; not the deliverance services of the prophets. Thirdly, the passages 
used to teach generational curses are often used without paying attention to the contrast they make about the differences of God's wrath and mercy. The verses show God's wrath as extending to the third and fourth generation while God's mercy and love extend to thousands of generations of those who love him. The gist of the message is that God's mercy outlives his wrath. Therefore the teaching on generational curses emphasises God's wrath by diminishing his mercy that endures forever (Ps 118). Fourthly, according to the Bible, Christ has, through his death on the cross, broken the power of the greatest curse pronounced by God on the whole universe (2 Cor 5:21; Gl 3:13). The only solution to the curse is faith in Christ through repentance. That Christ's death on the cross has broken the power of the generational curses challenges the ANP prophets' magnifying of the power of the curse. Although Christ's breaking of the universal curse is now, the full extent of it is not yet, and there is no biblical basis for ANP Christians to view their sufferings in this life as curses. A related point is that the New Testament does not teach Christians to view their suffering as curses or rejection by God but as God's act of discipline to mature their faith in him (Heb 12:7).

In African Christianity, a serious problem is that just like in ATR, the ANP belief in generational curses expresses intense spiritual insecurity and fear of the destructive evil spirits running within the family and one's community. This intense fear of generational curses among ANP Christian indicates a lack of confidence in the power of Jesus Christ and his salvation to independently and totally liberate and protect believers from the effects and power of the past sins of the ancestors. Others may justifiably argue that ANP prophets demonstrate confidence in Jesus Christ's power by using his name to break and reverse the generational curses. However, the problem is that in ANP Christianity, believers end up more reliant on the ability of the prophets to use the name of Jesus Christ effectively, instead of relying in faith on Christ's power to address their spiritual problems. The problem is that Christians eventually experience Christ's power as inaccessible to them unless mediated by the prophets. It is true that the ANP prophets use the name of Jesus in their deliverance services. However, the mediatory role they play instils high levels of lack of direct personal reliance on Christ's power by giving the impression that believers access Christ's greater power through the prophet's mediation.

This fear of generational curses among ANP Christians must be challenged by an awareness of God's securing power in his salvation as indicated in motifs such as adoption as God's children. The motif of adoption as children of God indicates God's spiritual security to his children that should give them confidence in their African context which is riddled with fear of evil spirits such as generational curses. The state of blessedness received by the Christian by being adopted as a child of God challenges the Christians from viewing their sufferings in this world from a perspective of generational curses.

\section{The soteriological motif of adoption as God's children}

The biblical idea of salvation as adoption into God's family is an important salvation motif in challenging the ANP fear of generational curses, because it communicates the certainty of salvation and assures Christians of their spiritual security in Christ.

\section{Adoption in its broader biblical perspective}

Adoption may be defined as a legal procedure through which a person leaves his or her own family and enters another family to legally be part of that family (Lyall 1969:459). It is a 'legal transfer of someone from one family to another' (Colijn 2010:178). However, in ancient Greco-Roman times adoption was always concerned with boys because the primary purpose was to save the name of the father undertaking the adoption from extinction. Various scholars explain that the Greek word huiothesia, meaning 'adoption' or 'sonship' is only used in Paul's letters and is not a Jewish concept and is not used in the Septuagint (LXX), but is found in GrecoRoman culture (Burke 1998:436, 2001:119; Fee 2011:145; Kruse 2012:337; Longenecker 1990:172). Furthermore, according to Burke (2001:120), Paul only uses adoption in letters he wrote to churches under Roman rule and law. Lyall (1969:459) states that the device of adoption was unnecessary and hence unknown in Jewish law'. The Old Testament law does not make any provisions for adoption and there is no mention of it as a Jewish practice (Burke 2001:120). ${ }^{2}$ Within the Israelite society polygamy and the levirate marriage obviated the need for adoption (Burke 2001:120). However, in the Jewish culture, the essence of adoption can be seen in God's choice of the nation of Israel as his special people with whom he had a parent-child relationship (e.g. Ex 4:22; Is 30:9; Hs 1:10; 11:1). Israel's prominent kings such as David and Solomon are described as enjoying a special father-son relationship with God (Ps 2:7; 2 Sm 7:14).

In the New Testament, Johannine literature depicts Christian salvation in parent-child terms in ways that suggest adoption (Jn 1:12). John adds that the Father has lavished a great love on us, that we should be called children of God (1 Jn 3:1a). These Johannine parent-child passages show that Christian conversion changes people's spiritual identity and status by changing them from God's enemies or lost people into God's children with whom he can have a personal relationship.

In salvation, adoption is a concept of 're-birth' and occurs at the point of one's conversion (Jn 1:12). Commenting on Ephesians 1:4, Bruce (1961:29) says, "“adoption" is ... ours by the new birth'. The motif of adoption captures the essence of being born again as one dies to their former life of sin and resurrects to a new life in Christ. As Erickson (1998:974) explains, adoption, 'occurs at the same time as do conversion, regeneration, justification, and union with Christ'. He adds,

2.In a footnote, Burke (2001:120) says Old Testament incidents that seem like adoption such as Abraham's slave Eliezer (Gn 15:2-3), Moses (Ex 2:10) and Esther (Es 2:7) took place on foreign soil governed by different laws. 
'Only those who are justified and regenerated are adopted, and vice versa' (Erickson 1998:974). Burke (2001:127) says for Paul, adoption is a term of conversion-initiation (Gl 3:26-4:7; Rm 8:15), and mentions baptism alongside adoption. Adoption is a Trinitarian event: God the Father adopts us through the redemptive work of his Son and takes up residence in our lives through the Holy Spirit (Eph 1.3, 12). In the next section Paul's unique use of adoption is analysed.

\section{The motif of adoption in Greco-Roman culture}

In light of the strong persuasion that Paul draws his motif of adoption from Greco-Roman culture, it is then important to understand how adoption was understood in that culture. However, the discussion will be limited to the state and status given by adoption to the adoptee. The Roman technical procedures in the adoption process fall outside the scope of this article. Burke (2001:121-124) provides a more detailed discussion on the technical details of the Greco-Roman adoption process. According to Burke (2001:121) the term 'adoption' is an essential part of the ancient familial matrix in Roman culture where family was 'the fundamental bedrock of society' (Burke 2001:121). Because of the importance of family in the Roman society, adoption played a significant role when a family was threatened with extinction because of the husband's inability to have his own children or when his children had failed to reach adulthood, leaving him without an heir and someone to preserve his name into posterity. In such circumstances, adopting a son from another family provided a means for the man to have an heir (Burke 2001:122). ${ }^{3}$ In the Greco-Roman culture the adopted person was always male because only sons could become heirs (Colijn 2010:185). Furthermore, according to Burke (2001:123), the normal subjects of adoption in the Roman world were already adults, who had demonstrated that they had greater chances of survival and the adopting father could see what he was getting as a son and heir.

While adoption saved the name of the man from extinction, it radically transformed the legal and social status of the adoptee. The radical changes are delineated by Lyall (1969) as follows:

The adoptee is taken out of his previous state and is placed in a new relationship with his new paterfamilias. All his old debts are cancelled, and in effect he starts a new life. From that time the paterfamilias owns all the property and acquisitions of the adoptee, controls his personal relationships, and has rights of discipline. On the other hand, he is involved in liability by the actions of the adoptee and owes reciprocal duties of support and maintenance. (p. 466)

In essence, the adoptee legally became a new person with a new social identity and standing as his former obligations and debts were cancelled. Douglas and Tenney (2011:27) point out that the former family regarded the son given away for adoption as dead to them. The cancellation of the old name and the receiving of a new name, the cancelation of 3.Burke (2001:122) adds that another possible options for the paterfamilias to have an heir was serial marriages. all past debts and the cessation of all old obligations and the assumption of a new legal standing and a social standing, all meant the beginning of a whole new life with new obligations. Paul seems to see this as what happens when a person is born again into Christ: 'Therefore, if anyone is in Christ, he is a new creation; the old has gone, the new has come!' (2 Cor 5:17).

Other significant changes effected by adoption were the change in hereditary succession because the adoptee's newly acquired legal position and privileges were the same as that of a legitimate biological son (Burke 2001:123). In the case of one who was a slave, adoption meant trading slavery for sonship with all its concomitant privileges (MacArthur 1987:109). Paul's use of adoption affirms that Gentile Christians are not second class citizens, but full citizens with equal rights as the Jews. In light of this Greco-Roman use of adoption, we must now discuss Paul's use of adoption in his doctrine of salvation and its implications on the ANP doctrine of generational curses. A question may be asked about an adoptee who longed for his biological parents and wished to return to his former life. In Romans 8, Paul uses adoption to call Christians to focus on their new glorious state in Christ and to forget about their past. Furthermore, in Galatians adoption indicates the foolishness of the Christian's return to the law of Moses. Therefore, adoption is such a glorious thing, it is unthinkable for anyone to desire to go back their former life.

\section{Paul's soteriological use of adoption}

The apostle Paul draws his motif of adoption from GrecoRoman culture. In Pauline literature adoption is an important soteriological motif that describes the status of the Christian believer. African neo-Pentecostal prophets need to carefully reconsider their teaching about generational curses in light of Paul's soteriological motif of adoption. The doctrine of generational curses portrays African Christians as second class citizens still bound by their former pre-conversion life and outside of Christ's protection. Paul uses the metaphor of adoption five times in all; three times in Romans (8:15, 23; 9:4), once in Galatians (4:5) and once in Ephesians (1:5). According to Longenecker (1990:172), huiothesia meaning adoption or sonship is 'a unique word to Paul's lips', but may have been common within the Judaism and among Jewish Christians in Paul's day. Deriving the concept from GrecoRoman culture and law, Paul uses adoption to explain the essence of being born again.

Paul's concept of sonship includes women (Gl 3:26-29), unlike in the Greco-Roman culture where the adopted heir was always male because only sons could become heirs (Colijn 2010:185). Paul uses sonship inclusively to point out that in Christian salvation, the privileged status only belonging to sons in Greco-Roman culture, now belongs to all saved men and women (G13:26-29). In this article 'sonship' and 'son' are used inclusively, because they meant a privileged position of heirship reserved for sons in the Roman society. 
Paul uses adoption to call Christians to live in accordance to their new glorious Christian nature ( $\mathrm{Rm} 8$ ) and to dissuade them from seeking salvation by observing the law (Gl 4:5). In Ephesians 1:5, Paul states, 'In love he [God] predestined us to be adopted as his sons through Jesus Christ, in accordance with his pleasure and will'. He presents adoption as a status that God pre-determined to give to all people who would receive his salvation through Christ (see also 1 Jn 3:1). God predestined that all who will accept Jesus as saviour will be adopted into his family. That adoption is 'through Jesus Christ' delineates that 'the mediating function of Jesus Christ is fundamental; through the Son we become sons [and daughters] of God' (Schnackenburg 1991:54). In Ephesians adoption is applied to Gentiles to affirm that those whom God once regarded as his enemies, who were cut off from God and were outside the commonwealth of God's people (Eph 2:1-3. 11-13), have now joined God's family with all the rights and privileges of the naturally born children (Klein 2006:49). The metaphor of adoption describes that Christian conversion is not just a change of status from being an enemy of God to a first kin member in God's family. Rather, adoption is the radical recreation of the new believer into a new person with a new life, which completely sets free the Christian from the allegiances, debts and responsibilities of their former life (Colijn 2010:186; Klein 2006:49). Adoption means the breaking of the chain linking the Christian to their former life. These soteriological insights are missing from the ANP belief that generational curses remain on Christians after being born again. Indeed, the Christian still remains with ties to their physical family, but spiritually they have a new family under the fatherhood of God in which Christ is described as their elder brother (Heb 2:9-11). While this new blessed family status may not change their material conditions in this life, it should shape how Christians interpret their suffering and pain in this present life.

In Romans 8 and Galatians 4, Paul uses similar arguments about adoption to emphasise, the obligations and privileges brought by adoption. ${ }^{4}$ In Romans 8, Paul tells Christians that adoption has freed them from the law, therefore they should not follow their sinful nature, but live righteously by following the Holy Spirit who indwells them and declares that they are children of God. As he states, 'those who are led by the Spirit of God are the children of God' (Rm 8:14). He adds that they received a Spirit that does not make them slaves, so that they live in fear again, but:

$[T]$ he Spirit you received brought about your adoption to sonship. And by him we cry, 'Abba, Father'. The Spirit himself testifies with our spirit that we are God's children. Now if we are children, then we are heirs - heirs of God and co-heirs with Christ. (Rm 15b-17a)

Paul shows the Holy Spirit as primary in the process of adoption by God. Therefore, because Christians received the Spirit at their conversion, they have been adopted as God's children with full rights to receive an inheritance from God their father. This basic soteriological fact of the blessedness of the Christian, calls into question the ANP doctrine that one 4.'Adoption conferred rights, but it came with a list of duties as well' (Davids 2001:25) can be a born-again Christian, be indwelt by the Holy Spirit and yet remain bonded by generational curses.

Paul affirms the full extent of adoption by pointing out that salvation has made believers, not just heirs of God, but are also co-heirs with Christ ( $\mathrm{Rm} 8: 17 \mathrm{a})$. To be 'heirs of God' means to be those whom God will give an inheritance, and to be 'co-heirs with Christ' means to be those who share the inheritance God will give to Christ (Kruse 2012:340). ${ }^{5}$ Concerning the Spirit's Abba cry, Longenecker (1990:174) says the content of the cry or acclamation epitomises the believer's new relationship with God: 'Father'. He adds that the use of 'Father' reflects Jesus' filial use of the term in the Gospels (Longenecker 1990:174). Believers now address God filially, as their 'Father', for they have become sons and daughters in his family. In the Romans 8 passage, the logic of adoption is employed to call Christians to shun ungodliness and live by the Spirit, even to the point of suffering for Christ. This perspective of adoption, invalidates the view that suffering is a generational curse on Christians by affirming Christians as not cursed, but blessed even though they may experience suffering in their life. God has liberated and sealed them with the seal of the Holy Spirit as his blessed prized possession (Eph 1:14-15).

In Galatians 4, Paul uses the similar points as in Romans 8, but to argue that God adopts us not by following the Torah, but by faith in Christ. He states in Galatians 4:5 that Christ was born under law 'to redeem those under the law, that we might receive adoption to sonship'. It is faith in Christ, and not obedience to the Torah, that qualifies one to be a son of Abraham, and ultimately the son of God who will receive the promised blessed inheritance. Accordingly:

Abraham's true 'sons', including Gentiles who through Christ share in the promised blessing, are none other than God's 'sons', having become so through the adoption that God's own Son effected for them. (Fee 2011:150)

\section{Consequently:}

[B]ecause you are sons, God sent the Spirit of his Son into our hearts, the Spirit who calls out, 'Abba, Father'. So you are no longer a slave, but a son; and since you are a son, God has made you also an heir. (Gl 4:6-7)

The former slaves are now free people who address God as father. Just as he stated in Romans 8:14-17, he states again in Galatians 4:6-7 that the gift of the Holy Spirit, who is received at the point of salvation, is the evidence of the certainty of adoption as sons and daughters of God. The indwelling presence of the Holy Spirit is the assurance of the Christian's adoption. The Spirit affirms the believer's filial relations with the Father; he assures them that they are now God's children with full rights of the heir.

Paul gives Trinitarian assurance of the believer's sonship by stating that at the right time God who sent his Son to redeem

5. However, from Romans $17 \mathrm{~b}$ to be co-heirs with Christ in the future demands that Christians identify with him in the present hostile world (Rm 8:17b, 2 Cor 4:17; Ac 14:22). 
us and make us his sons (Gl 4:4), he also sent 'the Spirit of his Son' into our hearts (Gl 4:6). The same Christ who died for them on the cross for their redemption, now indwells them through the Holy Spirit who was sent forth by the Father who sent forth the Son. This indicates Paul's 'basic monotheistic roots - that all of this, the work of the Son and the Spirit which effect and make effective our salvation, are ultimately attributed to God the Father' (Fee 2011:157). Therefore, " $t]$ he ultimate evidence of this "sonship" is their use of the Son's own address to the Father in prayer: $A b b a^{\prime}$ (Fee 2011:152). That the Holy Spirit's cry of 'Abba' comes from the heart of the believer indicates a form of intimacy with God and functions as the ultimate evidence that we are neither slaves, nor strangers, nor enemies of God, but his own children, who address him in the same term of intimate relationship that Jesus himself used (Fee 2011:155-156). The question is: how can one be in a loving relationship with God, address God as their father and be addressed by God as a daughter or son, and yet remain beholden in generational curses as suggested by the ANP prophets?

Longenecker (1990) explains that the primary function of the Spirit in the believer's life is not to cause him or her to become a 'spiritual' or 'charismatic' person, as is often assumed, but:

$[T]$ o witness to the filial relation of the believer with God that has been established by the work of Christ - a witness both to the believer and to God the Father. (p. 174)

The gift of the Holy Spirit affirms God's earnest desire 'to bring his people to a full realization of their personal relationship with him as sons and to a full possession of their promised inheritance' (Longenecker 1990:177). That is:

God himself, in the person of his Spirit, has come to indwell us; and he has sealed that relationship by giving to us the language of his Son, the language of personal relationship. (Fee 2011:156)

From a Trinitarian view, 'the indwelling Spirit, whom believers know as an experienced reality, is the way both the Father and the Son are currently present in the believer's life' (Fee 2011:151). Colijn (2010), quotes John Stott as saying:

God's purpose was not only to secure our sonship by His Son, but to assure us of it by His Spirit. He sent His Son that we might have the status of sonship, and He sent His Spirit that we might have an experience of it. (p. 186)

This denotes a state of freedom and blessedness that challenges the notion of a Christian living under generational curses.

However, it must be noted that Paul is mindful that our adoption is already, though in reality not yet fully, though it will be completed in the future final glory, for he says:

We know that the whole creation has been groaning as in the pains of childbirth up to the present time. Not only so, but we ourselves, who have the firstfruits of the Spirit, groan inwardly as we wait eagerly for our adoption to sons, the redemption of our bodies. ( $\mathrm{Rm} 8: 22-23)$
Paul shows that salvation is a present reality and but its full extent is in the future at Christ's glorious return. That is, 'although believers already can experience a filial relationship to God, their final adoption awaits the resurrection [at Christ's final return]' (Colijn 2010:187). Until then the adopted children still need to contend with the effects of the consequences of Adam's disobedience. African neo-Pentecostal Christians must note that Paul says the consequences of adoption by God includes identifying with him in this present hostile world (Rm 8:17b, 2 Cor 4:17; Ac 14:22). While adoption makes us God's blessed children, it does not exempt us from suffering, and to suffer is not a generational curse. The state of the blessedness of the Christian expressed by the motif of adoption challenges the ANP logic of generational curses on Christians.

\section{The challenge of adoption to the belief in generational curses}

The motif of adoption communicates spiritual security that challenges the ANP fear of generational curses on Christians.

\section{Adoption as redemption from Satan's dominion in God's kingdom}

To be adopted by God as a child is ultimately to be redeemed from the dominion of sin and be placed in a zone liberated and protected by God. Adoption entails deliverance and protection from slavery. Redemption is a term of costly freedom that carries the image of the ransoming of a captive or prisoner of war from slavery (Dunn 1998:227). In essence, redemption entails 'release or freedom on payment of a price, deliverance by costly method' (Douglas \& Tenney 2011:1218). In the Old Testament the basic essence of redemption is God's deliverance of Israel from their Egyptian slavery by freeing them from bondage and placing them in a free land. However, God redeemed Israel from Egypt not by paying anyone a ransom, but by his mighty power through which he defeated Pharaoh and broke his hold on Israel (Ex 6:6; Ps 77:14-15). In the New Testament Christ redeemed sinful humanity from Satan's slavery and power of sin by his sacrificial death on the cross and his resurrection from death (Heb 2:14-15). In Romans 8:14-17 and Galatians 4:7 redemption contrast adoption's freedom and slavery's imprisonment. Romans $6: 6,16-22$ indicate that Satan, the principal power of sin, is the slave master from which adoption redeems us. Even Paul's argument in Galatians 4:4 that the law of Moses is the slavery from which Christ came to redeem us, ultimately points to the enslaving power of sin because his bigger argument, is that Christ had to come because the law was in itself incomplete to overcome the power of sin. Blackwell (2016:145) points out that Paul's contrast of slavery and adoption shows that he associates adoption with freedom and liberation. By adopting Christians as his children, God redeemed them from the bondage of sin and admitted them into a new family that Christ brought into being by his death and resurrection (Douglas \& Tenney 2011:27). Christ's act of salvation is an act of freeing believers from Satan's fiefdom (Rm 6:14-19). This begs the question, if God has redeemed his people from Satan's slavery how then do ANP prophets 
teach that Christians remain under the hold of generational curses? It makes no theological sense to believe that a Christian adopted by God, secured by the mark of the Holy Spirit as God's child and made a co-heir with Christ, still remains under generational curses.

\section{Adoption as redemption from the guilt of sin}

The teaching on generational curses thrives on the notion of inherited guilt which is derived from the curses pronounced by God in Genesis 3 as a result of Adam's sin. Adoption by God shows freedom from sin's guilt and being reconciled to God (Col 1:13-14). Adoption signals cancellation of all past debts. In Christian salvation, although Satan held humanity in bondage because of their sin, humanity's sin did not offend him, but God. Therefore, adoption did not only redeem Christians from Satan's power, it also set them free from the guilt and penalty of sin. Paul states, in Christ 'we have redemption through his blood, the forgiveness of sins' (Eph 1:7). Adoption essentially means forgiveness of sins, which is the cancelation of sins that results in reconciliation with God. Therefore, Christ's redemptive work liberated humanity because his sacrificial death fully satisfied the requirement of God's justice for sins. By his sacrifice on the cross, Christ paid the ransom price needed to free humanity from its guilt of sin against God (Jn 8:33-34 \& Mk 10:45). The ransom sacrifice of Christ sufficiently atoned for the penalty of humanity's sins which created enmity between us and God (1 Jn 2:2); Christ's ransom sacrifice brought complete forgiveness and freedom from guilt. The effect of Christ's redemptive sacrifice is freedom from bondage and freedom in Christ secured by his blessed power.

Paul's statement that God sent into the hearts of Christians the Holy Spirit who calls out 'Abba, Father' (Gl 4:5-6) when he adopted them as his children, shows that 'adoption expresses both the redemption and new relation of trust and love' (Douglas \& Tenney 2011:27). Therefore, adoption, is deliverance from the past in similar fashion through regeneration and justification (Davids 2001:26). Adoption means Christians stand secure in God, and it challenges the ANP belief in generational curses by signifying the forgiveness of sins which leads to reconciliation with God in a secure relationship with him.

\section{Adoption as a new blessed spiritual state of being}

Spiritual security in adoption lies in God's transformation of the Christian's spiritual ontological state from a sinner deserving to die, or a foreigner without rights, to a child with full rights under God's protection. According to Erickson (1998:975), 'Adoption involves a change of both status and condition'. Blackwell (2016:144-145) adds that adoption points to 'the formation of a new people in relation to God resulting in a new ontological reality related to the resurrection experience'. This means 'those who are children of God become like him, inheriting his life' (Blackwell 2016:145). Our ontos [being], meaning state of being, changes from cursedness to blessedness, from vulnerability to security in God. As already noted from 2 Corinthians 5:17, the adopted person becomes a new creature; therefore, our cursed status by God because of sin, the condition of being a sinner and an enemy of God deserving God's wrath is transformed into a blessed status, and blessed children with full rights to receive the inheritance of the kingdom of God. Adoption has objective and subjective elements. Objectively, adoption is a legal declaration that changes our legal status into God's children (Erickson 1998:975). The seal of the Holy Spirit on us (2 Cor 1:22; Eph 1:13-14) is a mark of ownership or possession; therefore, the presence of the Spirit in the Christians marks them as God's property (Klein 2006:55).

Subjectively, adoption gives us a new view and experience of God as we look upon him as a loving Father we can trustingly relate with instead of a fearsome judge (Erickson 1998:975). Bruce (1961:29) shows the blessedness of adoption by pointing out that it is a 'highly honoured status' that 'embraces all the privileges and responsibilities which belong to those whom God has acknowledged as His freeborn, fullgrown sons'. At adoption, Christ becomes our redeemer and security and the Holy Spirit our comforter through his active indwelling presence in our lives. Since adoption transforms us into a new state of being, it calls into question the belief that one can be a born again Christian and yet continue to live under generational curses and by this make curses unbreakable bonds.

\section{The problems of using the motif of adoption in some African contexts}

In some African contexts appreciating the motif of adoption may be hindered by the negative connotation it has in some African traditional communities. Many African languages do not even have the word for adoption. Banda (2005:67-68) describes some spiritual problems that make adoption unfavourable in some ATR contexts. In ATR it is believed that there is an unbreakable bond between people and their ancestral spirits and that the African ancestral spirits and ancestral curses never relinquish their bonds on their descendants. Therefore, it is much safer to adopt a family member whose ancestral spirits are known, than strangers whose ancestral spirits are unknown (Banda 2005:65). If one's ancestors are unknown, it means in times of trouble the adopting family will not know how to appease the person's ancestors and how to entreat them to save the adopted member. Ancestors are believed to look after their own. In ATR, adoption does not delink the adoptees with the ancestral spirits of their original families. Following this perspective, many Africans believe their Christian conversion does not break their spiritual bonds with their ancestral spirits, meaning that the spirits continue to exert their control on the Christian. What is emphasised, is not the genealogical linkage, but the spiritual linkage. For example, according to the Shona traditional religion, uroyi hwedzinza hauperi, meaning the spirit of witchcraft inherited from one's lineage does not really end. Even after conducting ceremonies and rituals of driving out the evil spirit (ukulahlisa, in Ndebele; 
kurasisa, in Shona), it is believed the spirit may return if people do not maintain a proper spiritual disposition. Therefore, the essence of ATR religious ceremonies is fortification against the penetration of evil spirits into one's life. According to Biri's (2012:3-4) assessment the continuous desire for deliverance from evil spirits among ANP Christians reflects the ATR belief that it is difficult to break spiritual bonds from one's lineage. This ultimately makes generational curses unbreakable bonds of keeping an eye on Christians waiting to pounce on them if they fail to maintain a proper spiritual disposition.

Furthermore, in some ATR contexts, the security of adopted strangers is not fully guaranteed because the ancestors of the adopting families may reject them and withhold their protection or even work against the adoptees. Moreover, jealous family members may reject the adoptee and keep reminding him or her that they are a foreigner in the family and deny them a share of the family's inheritance. In some African traditional cultures, a person does not lose the identity of their origin, hence married women maintain their maiden surnames and continue to be addressed by them. This form of identity is ultimately linked to the ancestors. ${ }^{6}$

The insecurity of adoption in Africa can be demonstrated by the vulnerability faced by step-children. For instance, in Ndebele, a step-child brought by another spouse into a new marriage is called izalizelwe, literally, the one who came already born and communicates that one does not really belong to the new relationship and can be conveniently excluded from certain rights and responsibilities, such as claiming inheritance after the step-father's death. Similarly, in villages, a foreigner who has settled in the community can be pejoratively called idingandawo [seeker for a place to settle] or umuntuwokuza [foreigner] a tag that may be a permanent mark on the 'foreign' family and hinder it from claiming full rights and privileges within the village.

To a greater extent, the ANP teaching on generational curses reinforces these feelings of insecurity about adoption found in ATR. The doctrine of generational curses reinforces the idea that, just as an adopted African child may feel insecure because of being excluded by the ancestors of the family who have adopted him, and therefore need to supplement his own spiritual security by other means, African Christians must likewise supplement their spiritual security by relying on the deliverances offered by the prophets. Therefore, a problem with the doctrine of generational curses is that it leaves African Christians feeling like 'illegitimate children' from whom God has withheld his best blessings and protective care, leaving them to supplement their spiritual security by relying on prophets.

6.It often surprises many people when African children, who were rejected by their fathers fathers er their fathers who rejected them and had no part in their upbring to search for their fathers who rejected them and had no part in mother upbinging. From an ATR perspective, the children's decision to search for their father may be interpreted as agitated by their paternal ancestors who are calling their offspring to come to their rightful home.

\section{Towards a Christian life liberated from the fear of generational curses}

In light of the soteriological motif of adoption as God's children, what must Christians do to be liberated from the fear of generational curses promoted in African neoPentecostalism?

\section{Christians must live as people transformed into a blessed new state of being}

The motif of adoption conveys spiritual security by reminding Christians that God has transformed them into a new state of blessedness that secures them in his hands as his children. Barclay (2002) states:

We were absolutely in the power of sin and of the world; God, through Jesus, took us out of that power into his; and that adoption wipes out the past and makes us new. (p. 92)

Adoption has made us new by recreating us, cancelling our past and giving us a new beginning into a state of blessedness enacted by Christ's redemptive work. Adoption makes the Christian 'new in all spiritual respects' (Banda 2005:68). Adoption conveys spiritual security by communicating that Christians have been transformed into a new blessed being in Christ and translocated into the blessed realm in Christ (Banda 2005:69). This demands that African Christians discard living according a worldview informed by cursedness and condemnation. Rather, a born-again Christian should live according to a worldview informed by blessedness through Christ.

The motif challenges ANP prophets to stop their relentless weakening of Christian confidence by teaching unbiblical speculations about the great power of generational curses. Rather, they should empower the Christians by grounding them on the biblical fact that God has transformed his blessed children through adoption in Christ. There should be a focus on the new blessed state in Christ.

\section{Christians must stand on their family relationship with God established by Christ}

The ANP doctrine of generational curses is also a family relational issue, for cursedness means to be rejected by God the Father and to be consumed by the realm of evil. Yet, the motif of adoption as God's sons and daughters points to family intimacy with God established by and through Christ. God the Father relates directly with the Christian in whom the Holy Spirit cries, 'Abba, Father'. This family relationship between God and the believer challenges the spiritual insecurity that arises from the need to depend on the mediatory role of the ANP prophets to connect with God or to receive God's blessings. The ANP prophets do indeed teach Christ as the channel of connecting with God; but many times they also present themselves as the effective channels through whom Christians can receive God's blessings (Magezi \& Banda 2017:2-4). Makandiwa (2018b) says: 'There is something God can do to reverse a curse through a man of 
God' (italics added). Makandiwa is saying that God reverses curses through the prophet. Makandiwa (2018b) adds:

You don't deal with curses anyhow, when your blood is cursed and it's a curse affecting the whole generation, it means that even the blood will choose the church where the curse is not under any threat and that is what generational curses do. I don't know about you, but I would want a man of God who addresses the curse [sic]. (n.p.)

However, Makandiwa's statement is not informed by the mediatory role of Christ (2 Tm 2:2) and the family relationship between God and believers that enables believers to cry, 'Abba, Father' to God. When God adopted us 'he put his Spirit within us and we became subject to his control' (Douglas \& Tenney 2011:27). While ministers do play the important role of preaching, teaching and discipling Christians, it is having a father-child relationship with God through Christ that transforms them into a state of blessedness. Christians need to be taught that blessedness does not result from attending a deliverance service conducted by a prophet, but by receiving Christ's salvation which turns them into God's blessed children.

\section{Christians must view their suffering from a perspective of blessed children}

In its basic form the doctrine of generational curses is a theodicy. It is an ANP theory of why evil exists when there is a good God, and tries to absolve God by blaming suffering and evil to generational curses and demons (Makandiwa $2018 d, 2018$ e). However, the motif of salvation as adoption as God's children challenges Christians to be critical in how they view their suffering, because God has transformed them into his blessed children and placed them under his protective sovereign care. It must be realised that the Bible warns Christians that they are engaged in an ongoing spiritual warfare (Eph 6:10-19; 1 Pt 5:8) without classifying the devil's attack on the Christian as a curse. Even Job's gratuitous suffering is not classified as a curse in the Bible. Paul did not see himself as a cursed Christian when Satan attacked his life (2 Cor 12:7) and ministry (1 Th 2:18). Indeed, ANP prophets do well to remind Christians about the spiritual factor in the problem of human sufferings. However, it poses serious soteriological questions to attribute suffering to generational curses to the extent done by ANP prophets.

Paul affirms that our adoption as God's children does not absolve us from pain and suffering in this present world. However, a time is coming when all pain will end. As Paul stated:

I consider that our present sufferings are not worth comparing with the glory that will be revealed in us. For the creation waits in eager expectation for the children of God to be revealed. For the creation was subjected to frustration, not by its own choice, but by the will of the one who subjected it, in hope that the creation itself will be liberated from its bondage to decay and brought into the freedom and glory of the children of God. (Rm 8:18-21)
The radical newness brought by adoption on the Christian makes it soteriologically illogical for a Christian to continue to see his or her suffering as caused by generational curses. African neo-Pentecostal prophets are challenged to inform their theology of evil and suffering with the whole counsel of Scripture. If God has forgiven us all our sins, declared us his blessed children and made us heirs and co-heirs with Christ, it means that when we encounter suffering we must deal with it from a point of blessedness not cursedness.

\section{The human agency of African Christians must be empowered to address intergenerational problems}

The ANP belief in generational curses promotes human powerlessness by reinforcing the idea that human beings are passive victims of ancestral curses and evil spirits. This leads many Africans to live defeated lives. It is true that ultimately, problems such as poverty and sickness are spiritual, because of their origin in the fall of humanity in Genesis 3 that spoilt the good order of creation. However, the ANP belief in generational curses spiritualises human problems in a way that cripples African human agency and human responsibility. For instance, when Christians blame their promiscuity on the spirit of adultery (or the spirit of prostitution), they abrogate their human agency and responsibility in practising self-control and remaining sexually pure. This also fails to realise that the indwelling presence of the Holy Spirit and knowledge of God's word empowers Christians to be responsible and active participants in their sanctification (Gl 5:16-17). Teaching Christian spouses to love one another, to be unselfish by caring for each other's needs and teaching husbands to desist from gender-based violence are essential human acts and responsibilities of fighting the spirit of divorce' in families. Furthermore, in some situations intergenerational poverty is a structural issue promoted by the unfair distribution of economic resources, lack of access to economic resources, lack of needed economic knowledge and skills and poor economic practices by individuals. Therefore, intergenerational poverty cannot just be addressed by prophetic deliverance services without addressing people's economic powerlessness, wrong knowledge and attitudes about the economy and politics. There is also a need to empower Christians to act against systemic issues that promote poverty in their communities and countries. Much of Africa's poverty is a result of socioeconomic and political factors beyond the control of ordinary people. Instead of blaming poverty on spiritual factors, ANP prophets must also speak against unjust socioeconomic and political systems that result in high levels of poverty, poor medical care and a lack of economic skills. Therefore, instead of feeding their followers on fear of generational curses, African prophets must promote the human agency of their followers. The motif of adoption should remind African Christians that God is on their side ( $\mathrm{Rm} \mathrm{8:31)}$ and he has granted them his Holy Spirit to give them 'power, love and self-discipline' (2 Tm 1:7) and make them courageous active participants in solving their problems. 


\section{Conclusion}

The ANP teaching on generational curses promotes high levels of spiritual insecurity among many Christians. It has become common to hear many African Christians, even those from traditional mainline churches attributing their suffering to generational curses. The article attempted to answer the question: in light of the biblical description of Christians as adopted children of God, how should we soteriologically evaluate the ANP claim that born again Christians remain subject to curses inherited from their ancestors? The article challenged ANP Christians to use biblical soteriological motifs in addressing the fear of generational curses among their followers. The fear of generational curses reflects a poor understanding of soteriological changes worked by God in the Christian. The motif of adoption as God's children makes it questionable to believe that born-again Christians remain in chains of generational curses that are difficult to break unless they visit a powerful prophet. Generational curses seem like unbreakable chains that perpetually hang around Christians waiting for them to slip from God's hand to chain them again. They are like an evil power that lies dormant waiting to be activated by the believer's wrong doing. The motif of adoption challenges African Christians to awaken to the spiritual liberation and security that God provides for them as his blessed children.

\section{Acknowledgement}

I would like to thank Dr Dambudzo Penduka for reading the final draft of the manuscript and offering helpful comments for improving it.

\section{Competing interest}

I declare that there are no competing interest that exist.

\section{Authors' contributions}

I am the sole originator and author of this article.

\section{Ethical consideration}

This article followed all ethical standards for carrying out research without direct contact with human or animal subjects.

\section{Funding information}

This research received no specific grant from any funding agency in the public, commercial, or not for profit sectors.

\section{Data availability statement}

Data sharing is not applicable to this article as now new data were created or analysed in this study.

\section{Disclaimer}

The views and opinions expressed in this article are those of the author and do not necessarily reflect the official policy or position of any affiliated agency of the the author.

\section{References}

Asamoah-Gyadu, J.K., 2004, 'Mission to "set the captives free": Healing, deliverance, and generational curses in Ghanaian Pentecostalism', International Review of Mission 93(370/371), 389-406. https://doi.org/10.1111/j.1758-6631.2004. tb00468.x

Banda, C., 2005, The sufficiency of Jesus Christ in Africa: A christological challenge from African traditional religions, University of South Africa, Pretoria.

Banda, C., 2020, 'Regenerated without being recreated? A soteriological analysis of the African neo-Pentecostal teaching on generational curses', HTS Teologiese Studies/Theological Studies 76(3), a5941. https://doi.org/10.4102/ hts.v76i3.5941

Barclay, W., 2002, The letters to the Galatians and Ephesians, John Knox Press, Louisville, KY.

Biri, K., 2012, The silent echoing voice: Aspects of Zimbabwean Pentecostalism and the quest for power, healing and miracles, viewed 03 April 2014, from http://uir.unisa. ac.za/handle/10500/6609.

Biri, K., 2018, 'Health and wealth in Zimbabwean Pentecostalism: The case of the Zimbabwe Assemblies of God Africa (ZAOGA)', in L. Togarasei (ed.), Aspects of Pentecostal Christianity in Zimbabwe, pp. 73-89, Springer, Cham. https://doi. org/10.1007/978-3-319-78565-3_6

Blackwell, B.C., 2016, Christosis: Engaging Paul's soteriology with his patristic interpreters, Wm. B. Eerdmans Publishing, Grand Rapids, MI.

Bruce, F.F., 1961, The epistle to the Ephesians, Pickering \& Inglis, London.

Burke, T.J., 1998. 'Adoption and the Spirit in Romans 8', Evangelical Quarterly 70(4), 311-324.

Burke, T.J., 2001, 'Pauline adoption: A sociological approach', Evangelical Quarterly 73(2), 119-134.

Chitando, E. \& Biri, K., 2016, 'Walter Magaya's Prophetic Healing and Deliverance (PHD) ministries and Pentecostalism in Zimbabwe: A preliminary study with particular reference to ecumenism', Studia Historiae Ecclesiasticae 42(2), 72-85. https://doi.org/10.17159/2412-4265/2016/829

Colijn, B.B., 2010, Images of salvation in the New Testament, InterVarsity Press, Downers Grove, IL.

Davids, P.H., 2001, 'Adoption', in W.A. Elwell (ed.), Evangelical dictionary of theology, pp. 25-26, Baker Academic, Grand Rapids, MI.

Degbe, S.K., 2014, “"Generational curses" and the "four horns"', Journal of Pentecosta Theology 23(2), 246-265. https://doi.org/10.1163/17455251-02301007

Douglas, J.D. \& Tenney, M.C., 2011, Zondervan illustrated Bible dictionary, Zondervan, Grand Rapids, MI.

Dunn, J.D.G., 1998, The theology of Paul the apostle, W. B. Eerdmans, Grand Rapids, MI.

Erickson, M.J., 1998, Christian theology, 2nd edn., Baker Academic, Grand Rapids, MI. Fee, G.D., 2011, Galatians: Pentecostal commentary, Deo, Dorset.

Kgatle, M.S., 2017, 'The unusual practices within some Neo-Pentecostal churches in South Africa: Reflections and recommendations', HTS Teologiese Studies/ Theological Studies 73(3), a4656. https://doi.org/10.4102/hts.v73i3.4656

Kgatle, M.S., 2019, 'Reimagining the practice of Pentecostal prophecy in Southern Africa: A critical engagement', HTS Teologiese Studies/Theological Studies 75(4), a5183. https://doi.org/10.4102/hts.v75i4.5183

Klein, W.W., 2006, 'Ephesians', in T. Longman III \& D.E. Garland (eds.), The expositor's Bible commentary: Ephesians-Philemon, vol. 12, pp. 19-173, Zondervan, Grand Rapids, MI.

Kruse, C.G., 2012, Paul's letter to the Romans, Wm. B. Eerdmans Publishing, Grand Rapids, MI.

Longenecker, R.N., 1990, Galatians: World biblical commentary, Word, Dallas, TX.

Lyall, F., 1969, 'Roman law in the writings of Paul: Adoption', Journal of Biblical Literature 88(4), 458-466. https://doi.org/10.2307/3263796

MacArthur, J., 1987, Galatians, Moody Press, Chicago, IL.

Magezi, V. \& Banda, C., 2017, 'Competing with Christ? A critical Christological analysis of the reliance on Pentecostal prophets in Zimbabwe', In die Skriflig 51(2), a2273. https://doi.org/10.4102/ids.v51i2.2273

Mahohoma, T.C., 2017, 'A theological evaluation of God business: A case study of the Prophetic Healing and Deliverance Ministries of Zimbabwe', HTS Teologiese Studies/Theological Studies 73(2), a4529. https://doi.org/10.4102/ hts.v73i 2.4529

Makandiwa, E., 2018a, Bloodline curses 4, viewed 12 July 2019, from http://www. ufiministries.org/sermon/bloodline- curses-4/.

Makandiwa, E., 2018b, Bloodline curses: The voice of the blood, viewed 04 May 2019 from www.ufiministries.org/sermon/bloodline-curses/.

Makandiwa, E., 2018c, Exemption from the father's curse: Bloodline curses, DVD, UF Ministries, Harare.

Makandiwa, E., 2018e, Pre-Adamic generation: Disc A, DVD, UFI Ministries, Harare.

Makandiwa, E., 2018d, Pre-Adamic generation: Disc B, DVD, UFI Ministries, Harare.

Makandiwa, E., 2018f, The voice of the blood: Bloodline curses, DVD, Disc A, UFI Ministries, Harare. 
Makandiwa, E., 2018g, The word of God: Bloodline curses, DVD, UFI Ministries, Harare. Maxwell, D., 1998, “'Delivered from the spirit of poverty?": Pentecostalism, prosperity and modernity in Zimbabwe', Journal of Religion in Africa 28(3), 350-373. https:// doi.org/10.2307/1581574

Mbiti, J.S., 1990, African religions \& philosophy, 2nd edn., Heinemann, Educational Botswana, Gaborone.
Meyer, B., 1998, “"Make a complete break with the past": Memory and post-colonial modernity in Ghanaian pentecostalist discourse', Journal of Religion in Africa 28(3), 316-349. https://doi.org/10.1163/157006698X00044

Schnackenburg, R., 1991, The epistle to the Ephesians, T\&T Clark, Edinburgh.

Taringa, N., 2006, 'How environmental is African traditional religion?', Exchange 35(2), 191-214. https://doi.org/10.1163/157254306776525672 